\title{
Efficiency of garden waste compost teas on tomato growth and its suppressiveness against soillborne pathogens
}

\author{
María Remedios Morales-Corts*, Rodrigo Pérez-Sánchez, María Ángeles Gómez-Sánchez
}

University of Salamanca/Faculty of Agricultural and Environmental Sciences, Av. Filiberto Villalobos, 119 37007 - Salamanca - Spain.

*Corresponding author <reme@usal.es>

Edited by: Claudio Marcelo Gonçalves de Oliveira

Received November 07, 2016

Accepted June 27, 2017

\begin{abstract}
The use of compost teas is of great interest to sustainable agriculture. Aerated compost tea (ACT) and aerated vermicompost tea (AVT) originating from garden waste have been analytically characterized and tested in vitro and in vivo on tomato plants to determine their suppressive effect on Rhizoctonia solani and Fusarium oxysporum f. sp. lycopersici. The nitrogen $(\mathrm{N}, 3840 \mathrm{ppm})$ and potassium superoxide $\left(\mathrm{K}_{2} \mathrm{O}, 5800 \mathrm{ppm}\right)$ contents were relevant in ACT. Both ACT and AVT were shown to contain indoleacetic acid IAA (80 - $20 \mathrm{mg} \mathrm{L}^{-1}$ ), salicylic acid (5.85 - $\left.1.33 \mathrm{ng} \mathrm{L}^{-1}\right)$ and humic acids $\left(190-140 \mathrm{mg} \mathrm{L}^{-1}\right)$. Direct confrontation assays against the pathogens showed that ACT had a high suppressive effect on F. oxysporum f. sp. lycopersici (relative growth of the pathogen [RG]: $12 \%$ ) and AVT had a high suppressive effect on $R$. solani (RG: $18 \%$ ). These suppressive effects have been confirmed by tests performed in vitro and on potted tomato plants. Results of plants growth assays showed that both teas can be applied, in their concentrated forms, to the growth medium. The analysis of the growth effect of the teas on tomato plants clearly indicated that both ACT and AVT, when applied weekly, produce a positive effect on shoot and root dry weight (dry weights were tripled), chlorophyll content and stem diameter compared to untreated plants. These results support the use of ACT and AVT as potential alternatives to the application of synthetic fungicides, and as plant promoters in crop production, for attaining environmental sustainability for farming and food safety.
\end{abstract}

Keywords: Solanum lycopersicum, compost and vermicompost, growth effect, sustainable agriculture

\section{Introduction}

Compost teas are organic solutions obtained by the fermentation of compost in a liquid phase for a few days, with or without aeration. Generally, extracts are prepared by mixing mature compost with tap water in the ratios of 1:5 to $1: 10(\mathrm{v} / \mathrm{v})$ (Al-Dahmani et al., 2003). The use of these teas in agriculture is emerging because of their ability to suppress a wide range of both soil and airborne pathogens (Martin, 2014). In this regard, compost teas are viewed as potential alternatives to the use of common synthetic fungicides in response to the increasing need for environmental sustainability of farming and food safety (Pane et al., 2012). The effectiveness of compost teas may vary due to differences in types of compost, management and procedures used for its preparation (Egwunatum and Lane, 2009; Pant et al., 2012). Martin (2014) indicated that the best results are obtained when aerated compost teas rather than non-aerated teas are replied, probably because dissolved oxygen supports microbial activity (Arancon et al., 2007). Following Reeve et al. (2010), the potential of compost teas for supplementing or substituting other types of fertilizers also seems promising, but further testing under both greenhouse conditions and in the open field is still required. Composted green wastes are considered advantageous compared with other organic wastes since they present a lower risk of toxicity due to the presence of heavy metals, pollutants, aromatic hydrocarbons, hormones, pharmaceuticals as well as viruses, fecal coliforms and salmonella (Benito et al., 2005;
Moretti et al., 2015), and because of the interesting biological activity of these materials (Ros et al., 2005).

Furthermore, Rhizoctonia solani and Fusarium oxysporum are important soilborne pathogens that cause disease in a large number of cultivated plants, particularly in tomato crop production. Currently, tomato is grown on every continent and represents the horticultural product with the highest economic importance, with more than 90 million tons produced annually worldwide (FAO, 2015). Horticulture, has become highly dependent on chemical pesticides and fumigants for the control of plant pathogens, which have drastic effects on the soil biota (Pascual et al., 2002), and their use has been restricted due to problems associated with environmental damages and health hazard (Siddiqui et al., 2008; 2009). As one of the alternative solutions, the use of compost tea could be considered a potential method for reducing the use of chemical fungicides.

In the present study, aerated compost and vermicompost teas obtained from garden wastes were analytically characterized and their effects on $R$. solani and $F$. oxysporum f. sp. Lycopersici, as well as their capacity for promoting plant growth, were tested.

\section{Materials and Methods}

\section{Preparation of compost teas}

Compost and vermicompost were based on green and pruning residues, which came from gardens in the province of Salamanca (Spain), and were collected by a 
horticultural company located in the city of Salamanca (40 $57^{\prime} 23^{\prime \prime} \mathrm{N}$; 5 $41^{\prime} 8^{\prime \prime} \mathrm{W}, 775 \mathrm{~m}$ a.s.1.). Most of the material collected consisted of the leaves and stems of different Cupressaceae species and grass clippings. Some of this waste was turned into compost in piles at the factory. The composting process was carried out using aerated-piles measuring $15 \mathrm{~m}$ by $2 \mathrm{~m}$ (sides) and $2 \mathrm{~m}$ in height. The piles were turned twice per week over 8 weeks and once a week during the rest of the bio-oxidative process. Pile moisture was controlled weekly and the composting process lasted 180 days. Another portion of the green and pruning waste was turned into vermicompost over a 6 month period, where Eisenia foetida, with a stoking density of $1.6 \mathrm{~kg}$ worms $\mathrm{m}^{-2}$, were added to the waste in raised soil beds that were constructed in a non-controlled greenhouse. Each bed measured $3 \mathrm{~m} \times 1 \mathrm{~m} \times 0.43 \mathrm{~m}$ (Morales-Corts et al., 2014). Compost and vermicompost were mixed with tap water in a ratio of $1: 5(\mathrm{v} / \mathrm{v})$ in polyethylene non-degradable $25 \mathrm{~L}$ containers at room temperature for a brewing period lasting 14 days. Water had been previously aerated for $8 \mathrm{~h}$ to reduce the amount of chlorines present in it. The mixtures were aerated using an aquarium pump ( $4 \mathrm{~h}$ every day). Next, the liquid was filtered through a double layered cheesecloth to obtain the aerated compost tea (ACT) and the aerated vermicompost tea (AVT), which were both stored in dark polyethylene containers at room temperature for 15 days before use. Nine samples of ACT and AVT were obtained.

\section{Analytical characterization of compost teas}

The $\mathrm{pH}$ and electrical conductivity (EC) were determined by using a CRISON pH-meter and a CRISON EC-meter $\left(\mathrm{dS} \mathrm{m}^{-1}\right)$, respectively. Total $\mathrm{N}$ was determined by a LECO-device analyser. $\mathrm{NO}_{3}{ }^{-}, \mathrm{NH}_{4}{ }^{+}$and $\mathrm{SO}_{4}{ }^{2-}$ were analysed by a HANNA HI 993310 photometer. Phosphorus $\left(\mathrm{P}_{2} \mathrm{O}_{5}\right)$ was determined by the Bray method and potassium $\left(\mathrm{K}_{2} \mathrm{O}\right)$ by the ammonium acetate method. Total magnesium $(\mathrm{Mg})$, calcium $(\mathrm{Ca})$, iron $(\mathrm{Fe})$, copper $(\mathrm{Cu})$, zinc $(\mathrm{Zn})$, boron $(\mathrm{B})$, manganese $(\mathrm{Mn})$, chromium $(\mathrm{Cr})$, lead $(\mathrm{Pb})$, mercury $(\mathrm{Hg})$, nickel $(\mathrm{Ni})$ and cadmium $(\mathrm{Cd})$ were determined by using inductively coupled plasma atomic emission spectroscopy. Salicylic acid and indoleacetic acid (IAA) were quantified by mass spectrometry (HPLC). Humic acids were determined using the alkali/ acid fractionation method following the procedure indicated by Pant et al. (2012). The number of fecal and total coliform bacteria was determined following ISO 16649-3 standard (ISO, 2015) while the presence of Salmonella was analyzed by ISO 6579 (ISO, 2002). The nine samples of ACT and AVT were analysed and the means of the parameters were calculated. Student's t-test was carried out to validate the significance of the differences among compost and vermicompost tea composition $(p<0.05)$. The SPSS 24.0 program was used for the calculations.

\section{In vitro assays \\ Dosage assays - Solanum lycopersicum Mill. cv. Roma seedlings with one true leaf were grown in cap-}

less $10 \mathrm{~mL}$ test tubes. To determine if the teas could be applied directly, or needed to be diluted, three concentrations of teas were tested: non-diluted tea (ACT1 and AVT1); 1 tea: 2 water v/v (ACT2 and AVT2); and 1 tea: 4 water v/v (ACT3 and AVT3). Five $\mathrm{mL}$ of each corresponding tea, $4 \mathrm{~mL}$ of a Meier-Schwarz nutrient solution and $1 \mathrm{~mL}$ of distilled water were added to each tube. A control containing $4 \mathrm{~mL}$ of the nutrient solution and 6 $\mathrm{mL}$ of distilled water was also included. In total ten samples per treatment were prepared. Twenty-eight days after the samples had been prepared the following growth parameters were determined: leaf area $(0.34[\mathrm{~L} * \mathrm{~W}]-1.71$ (Astegiano et al., 2001); L [length] and W [width] were measured with a digital calliper with a sensitivity of $0.01 \mathrm{~mm}$ ); chlorophyll content (SPAD-502) and dry weight (plants were dried in an oven P-Selecta-210 at $70{ }^{\circ} \mathrm{C}$ for $48 \mathrm{~h}$ ). In parallel, treatments to evaluate suppressive effects on $F$. oxysporum f. sp. lycopersici and $R$. solani were also set up. One $\mathrm{mL}$ of $10^{7} \mathrm{cfu}$ (colony-forming units) $\mathrm{mL}^{-1}$ of $F$. oxysporum f. sp. lycopersici (strain 2,715, from the collection of The Regional Center for Pest and Diseases Diagnosis, Junta de Catilla y León, Spain) was inoculated into each test tube containing one tomato seedling. $R$. solani (strain 122, from the same collection) was inoculated by adding $3 \mathrm{~mL}$ of a mycelial suspension per test tube. The same amounts as above of each concentration of ACT and AVT were added, and either $4 \mathrm{~mL}$ (for tubes with $F$. oxysporum f. sp. lycopersici) or $2 \mathrm{~mL}$ (for tubes with $R$. solani) of nutrient solution were added to each assay. Controls with each respective pathogen, without the teas, were set up and distilled water was added to these test tubes making a total volume of $10 \mathrm{~mL}$.

To obtain $F$. oxysporum f. sp. lycopersici inoculum, 1 $\mathrm{cm}^{2}$ of the pathogen, recently grown in PDA (Potato Dextrose Agar), was added to $100 \mathrm{~mL}$ of liquid medium PDB (Potato Dextrose Broth). This culture was maintained under continuous agitation $\left(125 \mathrm{rpm}, 25^{\circ} \mathrm{C}\right)$ for 5 days. The medium was then filtered and centrifuged $(5,000 \mathrm{rpm}$, $15 \mathrm{~min}$ ). The precipitate was re-suspended in $1 \mathrm{~mL}$ of distilled water. Finally, colony-forming units (cfu) were counted in a Thoma chamber and the inoculum concentration was then adjusted to $10^{7} \mathrm{cfu} \mathrm{mL}^{-1}$. The $R$. solani inoculum was prepared using the contents of two petri cultures (recently grown) that were macerated in a waring blender with $400 \mathrm{~mL}$ of $\mathrm{ddH}_{2} \mathrm{O}$. The final concentration of the suspension was $10^{3}$ mycelial fragments $\mathrm{mL}^{-1}$. The inoculum density was quantified by the dilution plating technique (Paulitz and Schroeder, 2005).

In addition to determining the various growth parameters already mentioned, the incidence of pathogen attack was also calculated. The severity of the attack by F. oxysporum f. sp. lycopersici was rated numerically (0-5) following the method established by Bayen and van der Plas (1992). The severity of the attack by $R$. solani was assessed using the scale (0-4) described by Carling and Leiner (1990). The assays were carried out in a greenhouse (temperatures of $18{ }^{\circ} \mathrm{C}$ night, $24{ }^{\circ} \mathrm{C}$ day and $80 \%$ relative humidity) and were repeated twice, once in Apr 
2013 and once again in June 2013. Ten samples per treatment were always prepared. The differences between treatments were determined using analysis of variance (ANOVA). When significant differences were observed between treatments, the Tukey range test $(p<0.05)$ was also carried out. The SPSS 24.0 program was used for the calculations involved.

\section{Direct effect on pathogen growth}

A second in vitro study was carried out in order to analyse the effect of ACT and AVT on the relative growth of the pathogen in petri dishes. ACT- and AVTcontaining media were prepared by adding teas separately (in a proportion of $10 \% \mathrm{v}$ ) to melted PDA, at 60 ${ }^{\circ} \mathrm{C}$, and mixed. The PDA supplemented with either compost or vermicompost tea was immediately poured into $90 \mathrm{~mm}$ standard petri dishes and $R$. solani and $F$. oxysporum f. sp. lycopersici were inoculated into the medium by placing a $5 \mathrm{~mm}$ diameter PDA plug of actively growing mycelium in the middle of the plate. Controls consisted of adding sterile distilled water instead of compost teas to the medium. Five replicates per treatment were made and colony diameter of the pathogen was measured 2, 7 and 13 days after inoculation. The relative growth of the colony (RG) was calculated as the area of colony growth on plates containing the teas in relation to the area that developed in PDA without the teas (Köller and Wilcox, 2001). Moreover, on each plate, colony-forming units (cfu) of the different microorganisms from ACT and AVT were detected in the medium after 2 and 7 days. Total cfu were directly counted (stereomicroscope). This experiment was repeated three times.

\section{In vivo assays}

In order to evaluate the application of ACT and AVT on tomato growth and the suppressive effect on $F$. oxysporum f. sp. lycopersici and $R$. solani pathogens, different treatments (ACT, AVT, Control, Fusarium + ACT, Fusarium + AVT, Fusarium control, Rhizoctonia + ACT, Rhizoctonia + AVT and Rhizoctonia control) were established in pots using a randomized arrangement with 15 plants per treatment. Seedlings with two true leaves (Roma cv.) were transplanted into pots (2 L capacity) containing vermiculite medium. One $\mathrm{mL}$ of nutrient solution and $40 \mathrm{~mL}$ of each corresponding tea (ACT or AVT) were applied to each plant weekly. The assay was carried out in a greenhouse over two consecutive years (2014 and 2015), where the plants were grown under typical tomato growing conditions (temperatures of 18 ${ }^{\circ} \mathrm{C}$ night, $24^{\circ} \mathrm{C}$ day and $80 \%$ relative humidity), for ten weeks during the months of Apr, May and June until they flowered. The pathogens were applied one week after transplanting the seedlings into the pots. Ten $\mathrm{mL}$ of mycelial suspension $\left(10^{3}\right.$ mycelial fragments $\left.\mathrm{mL}^{-1}\right)$ of $R$. solani were inoculated per pot. $F$. oxysporum f. sp. lycopersici was inoculated by adding $10 \mathrm{~mL}$ of $10^{7} \mathrm{cfu}$ $\mathrm{mL}^{-1}$ to each pot. Both pathogen inoculations were conducted by dispensing near the hypocotyl and roots us- ing a disposable pipette (the preparation of inocula was described in the in vitro assays). Plants were watered by a sub-irrigation system when needed. At the end of the experiments the following parameters were measured: diameter, determined with a digital calliper with a sensitivity of $0.01 \mathrm{~mm}$; chlorophyll content (SPAD-502); dry root weight, dry shoot weight and total dry weight (plants were dried in an P-Selecta- 210 oven at $70{ }^{\circ} \mathrm{C}$ for $48 \mathrm{~h}$ ). Moreover, the severity of the pathogen attack was evaluated using the same method outlined in the in vitro assays. Differences between treatments were determined by ANOVA and where significant differences were found, a Tukey range test $(p<$ 0.05) was also carried out. The SPSS 24.0 program was used for the calculations.

\section{Results}

\section{Analytical characterization of compost teas}

Characteristics, such as $\mathrm{pH}, \mathrm{EC}$, plant nutrients, humic acids, phytohormomes, and heavy metals contents, are shown in Tables 1 and 2. The $\mathrm{pH}$ values were based on garden waste compost and vermicompost teas, being 7.81 in ACT and 7.53 in AVT. Electrical conductivity was significantly $(p<0.05)$ higher in ACT $(2.46 \mathrm{mS}$ $\left.\mathrm{cm}^{-1}\right)$ than in AVT $\left(0.55 \mathrm{mS} \mathrm{cm}^{-1}\right)$. Total $\mathrm{N}, \mathrm{NO}_{3}{ }^{-}$and $\mathrm{K}_{2} \mathrm{O}$ contents were significantly lower in AVT than in ACT, while $\mathrm{NH}_{4}{ }^{+}, \mathrm{P}_{2} \mathrm{O}_{5}, \mathrm{Ca}, \mathrm{Mg}$ contents reached similar values in both teas (Table 1). Humic acids were determined in both teas, being higher in ACT (190 $\left.\mathrm{mg} \mathrm{L}^{-1}\right)$, though not significant when compared to AVT.

Moreover, very high values of the phytohormones salicylic acid and indoleacetic acid were found in ACT, (5.85 $\left.\mathrm{mg} \mathrm{L}^{-1}\right)$ and $\left(80 \mathrm{ng} \mathrm{L}^{-1}\right)$, respectively. AVT also presented significant amounts of these phytohormones, but significantly lower than in ACT. Fe, $\mathrm{Zn}, \mathrm{Mn}$ and $\mathrm{Cu}$ trace elements were found in ACT and AVT with Mn being significantly higher in ACT than in AVT (Table 2). The element B was detected in ACT (17.2 ppm), but not in

Table 1 - Analytical characterization of garden wastes compost (ACT) and vermicompost (AVT) teas (mean \pm standard deviation).

\begin{tabular}{|c|c|c|}
\hline & ACT & AVT \\
\hline $\mathrm{pH}$ & $7.81 \pm 0.15 a$ & $7.53 \pm 0.17 a$ \\
\hline $\mathrm{EC}\left(\mathrm{mS} \mathrm{cm} \mathrm{cm}^{-1}\right)$ & $2.6 \pm 0.09 a$ & $0.5 \pm 0.15 b$ \\
\hline N (ppm) & $3840.6 \pm 200 a$ & $815.3 \pm 163 b$ \\
\hline $\mathrm{NH}_{4}^{+}(\mathrm{ppm})$ & $16.1 \pm 9.2 \mathrm{a}$ & $4.5 \pm 4 a$ \\
\hline $\mathrm{NO}_{3}-(\mathrm{ppm})$ & $3820.9 \pm 193.8 \mathrm{a}$ & $808.5 \pm 0.15 b$ \\
\hline $\mathrm{P}_{2} \mathrm{O}_{5}(\mathrm{ppm})$ & $149.7 \pm 18.3 \mathrm{a}$ & $148.1 \pm 16.2 \mathrm{a}$ \\
\hline $\mathrm{K}_{2} \mathrm{O}(\mathrm{ppm})$ & $5600 \pm 231.5 a$ & $250 \pm 48.2 b$ \\
\hline $\mathrm{SO}_{4}^{2-}(\mathrm{ppm})$ & $60 \pm 18 a$ & $30 \pm 25 a$ \\
\hline Ca (ppm) & $50 \pm 23 a$ & $75 \pm 31 a$ \\
\hline $\mathrm{Mg}(\mathrm{ppm})$ & $27.5 \pm 16 a$ & $10.0 \pm 6 a$ \\
\hline Humic acid (mg L-1) & $190 \pm 40 a$ & $140 \pm 31 a$ \\
\hline Salicylic acid (mg L-1) & $5.85 \pm 1.23 a$ & $1.33 \pm 0.24 b$ \\
\hline IAA (ng $\left.L^{-1}\right)$ & $80 \pm 10 a$ & $20 \pm 6 b$ \\
\hline
\end{tabular}

Different letters in the same file indicate significant differences $(p<0.05)$; Number of samples $(n=9)$. 
AVT. $\mathrm{Pb}$ and $\mathrm{Ni}$ were present in very small accounts in both teas, while $\mathrm{Hg}, \mathrm{Cr}$ and $\mathrm{Cd}$ were not detected. A very low number of total coliform bacteria was found and no Salmonella was detected. The compositions of both compost teas were within the acceptable limits of composting standards as reported in Spanish legislation (BOE, 2013) and by Aendekerk et al. (2000).

\section{In vitro assays}

Dosage assays - The effect of three compost tea concentrations on leaf area, chlorophyll content and dry tomato seedling weight are shown in Table 3. Significantly higher values of dry weight, chlorophyll content and leaf area were obtained with non-diluted ACT and AVT than with diluted ones. No significant differences were observed between the control and when the 1:4 diluted teas were applied. A significant increase in leaf area was achieved with the 1:2 diluted AVT compared to

Table 2 - Harmful bacteria and metal composition of garden waste compost (ACT) and vermicompost (AVT) teas (mean \pm standard deviation).

\begin{tabular}{|c|c|c|}
\hline & ACT & AVT \\
\hline $\mathrm{Fe}(\mathrm{ppm})$ & $9.8 \pm 2.1 \mathrm{a}$ & $7 \pm 2.6 \mathrm{a}$ \\
\hline B (ppm) & $17.2 \pm 6.3$ & * \\
\hline $\mathrm{Zn}(\mathrm{ppb})$ & $2655 \pm 245 a$ & $2819 \pm 269 a$ \\
\hline Mn (ppb) & $587 \pm 189 a$ & $182 \pm 95 b$ \\
\hline $\mathrm{Cu}(\mathrm{ppb})$ & $3084 \pm 467 a$ & $3403 \pm 335 a$ \\
\hline $\mathrm{Pb}(\mathrm{ppb})$ & $88 \pm 12 a$ & $89 \pm 9 a$ \\
\hline $\mathrm{Hg}(\mathrm{ppb})$ & * * & ** \\
\hline $\mathrm{Cr}(\mathrm{ppb})$ & ** & ** \\
\hline $\mathrm{Ni}(\mathrm{ppb})$ & $112 \pm 35 a$ & $85 \pm 28 a$ \\
\hline $\mathrm{Cd}(\mathrm{ppb})$ & ** & ** \\
\hline Total coliform (npm g-1) & $0.7 \pm 0.1 \mathrm{a}$ & $0.6 \pm 0.13 a$ \\
\hline Faecal coliform (npm g-1) & $0.3 \pm 0.2 \mathrm{a}$ & $0.3 \pm 0.1 a$ \\
\hline Salmonella bacteria & absent & absent \\
\hline
\end{tabular}

Different letters in the same column indicate significant differences $(p<0.05)$; Number of samples $(\mathrm{n}=9)$; ; ${ }^{*}$ Not detected $<0.2 \mathrm{ppm}$; ${ }^{*}$ Not detected $<$ $0.1 \mathrm{ppb}$. the control, but this was not the case for the 1:2 diluted ACT, which did not vary within any of the parameters analysed.

The severity of the $F$. oxysporum f. sp. lycopersici attack was considerably reduced when non-diluted ACT and AVT were applied (Table 4). Very small growth parameter results were obtained when ACT1 was used to treat inoculated tomato seedlings. AVT diluted 1:2 and 1:4 and ACT diluted 1:2 slightly reduced attack severity compared to control. No positive results were obtained with ACT diluted 1:4, showing attack results similar to those of the F. oxysporum f. sp. lycopersici control. The pathogen was not $100 \%$ controlled in any of the cases.

The attack severity of $R$. solani was $100 \%$ controlled when non-diluted AVT was applied (Table 5). AVT2 and ACT1 considerably reduced attack severity. High growth parameter results were obtained when AVT1 was applied on tomato seedlings inoculated with $R$. solani and similar results for leaf area and dry weight were observed when using ACT1. Based on the values obtained for the in vitro assays we were able to conclude that non-diluted compost teas should be used for the in vivo assays as this concentration produced the best results.

\section{Direct effect on pathogens growth}

As shown in Table 6, the addition of AVT to the PDA medium resulted in an RG lower than $50 \%$ for $R$. solani and $F$. oxysporum f. sp. lycopersici, which was considered the reference value for determining a high suppressor effect (Bernal-Vicente et al., 2008). The addition of ACT to the medium produced a very high suppressive effect on F. oxysporum f. sp. lycopersici (RG $12 \%$ ) but did not reach a suppressive effect of $50 \%$ on $R$. solani. The growth diameter of $R$. solani grown on plates containing ACT and AVT was similar to the control on the second day; however, by day 7 the effect of growth inhibition over $R$. solani was clearly observed. A very high value of inhibition was recorded with AVT (RG: $18 \%$ ) on day 13. By day 7 the cfu observed with the addition of AVT and ACT were above 1,000 in both cases. The suppressive effect of ACT and AVT on $F$. oxysporum $\mathrm{f}$. sp. lycopersici growth was similar to that on $R$. solani also starting on day 2. Pathogen growth on days 7 and 13 clearly exhibited

Table 3 - Growth effect of different dosages of composition of vermicompost (AVT) and garden waste compost (ACT) teas on tomato seedlings (mean \pm standard deviation).

\begin{tabular}{lccccccc}
\hline & Control & AVT1 & AVT2 & AVT3 & ACT1 & ACT2 & ACT3 \\
\hline Leaf area $\left(\mathrm{mm}^{2}\right)$ & $21.3 \pm 1.8 \mathrm{a}$ & $26.2 \pm 0.6 \mathrm{c}$ & $24.5 \pm 0.5 \mathrm{~b}$ & $23.0 \mathrm{ab}$ & $25.9 \pm 0.5 \mathrm{c}$ & $23.2 \pm 2.1 \mathrm{ab}$ & $22.9 \pm 1.5 \mathrm{a}$ \\
Chlorophyll content SPAD units & $20.1 \pm 1.9 \mathrm{a}$ & $24.9 \pm 0.6 \mathrm{~b}$ & $23.4 \pm 2.3 \mathrm{ab}$ & $23.9 \pm 2.1 \mathrm{ab}$ & $22.7 \pm 1.9 \mathrm{ab}$ & $21.9 \pm 0.3 \mathrm{a}$ & $21.6 \pm 0.4 \mathrm{a}$ \\
Total dry weight $(\mathrm{mg})$ & $47.7 \pm 3.4 \mathrm{a}$ & $65.0 \pm 5.1 \mathrm{~b}$ & $54.7 \pm 3.2 \mathrm{ab}$ & $52.7 \pm 2.1 \mathrm{a}$ & $64.2 \pm 2.3 \mathrm{~b}$ & $49.4 \pm 1.8 \mathrm{a}$ & $47.2 \pm 3.3 \mathrm{a}$ \\
\hline
\end{tabular}

Different letters in the same row indicate significant differences $(p<0.05)$; Number of samples $(n=10)$. AVT1 and ACT1 = non-diluted teas; AVT2 and ACT2 (dilution

1 tea:2 water v/v); AVT3 and ACT3 (dilution 1 tea:4 water v/v).

Table 4 - Growth effect on tomato seedlings and attack severity of Fusarium oxysporum f. sp. lycopersici using different dosages of vermicompost (AVT) and garden waste compost (ACT) teas (mean \pm standard deviation).

\begin{tabular}{|c|c|c|c|c|c|c|c|c|}
\hline & Control & $\begin{array}{c}\text { Fusarium } \\
\text { Control }\end{array}$ & $\begin{array}{c}\text { Fusarium } \\
\text { AVT1 }\end{array}$ & $\begin{array}{c}\text { Fusarium } \\
\text { AVT2 }\end{array}$ & $\begin{array}{c}\text { Fusarium } \\
\text { AVT3 }\end{array}$ & $\begin{array}{c}\text { Fusarium } \\
\text { ACT1 }\end{array}$ & $\begin{array}{c}\text { Fusarium } \\
\text { ACT2 }\end{array}$ & $\begin{array}{c}\text { Fusarium } \\
\text { ACT3 }\end{array}$ \\
\hline Leaf area $\left(\mathrm{mm}^{2}\right)$ & $21.3 \pm 1.8 \mathrm{a}$ & $15.1 \pm 3.1 b$ & $21.7 \pm 1.8 \mathrm{a}$ & $18.0 \pm 2.8 \mathrm{ab}$ & $16.4 \pm 1.3 b$ & $20.4 \pm 1.8 \mathrm{a}$ & $16.4 \pm 1.9 b$ & $14.7 \pm 1.2 b$ \\
\hline Chlorophyll content SPAD units & $20.1 \pm 1.9 a$ & $13.6 \pm 1.2 \mathrm{c}$ & $22.6 \pm 1.8 \mathrm{a}$ & $19.8 \pm 2.8 a b$ & $17.9 \pm 1.8 a b$ & $21 \pm 1.1 \mathrm{a}$ & $19.8 \pm 2.7 \mathrm{ab}$ & $11.7 \pm 1.8 \mathrm{c}$ \\
\hline Total dry weight (mg) & $47.7 \pm 5.4 a b$ & $33.6 \pm 2.3 c$ & $42.2 \pm 3.4 b$ & $39.3 \pm 2.8 b$ & $36.9 \pm 4.3 b c$ & $54.4 \pm 3.6 \mathrm{a}$ & $37.9 \pm 3.5 a b$ & $35.3 \pm 2.1 c$ \\
\hline Attack severity & $0 \mathrm{~d}$ & $4 a$ & $1 \mathrm{c}$ & $3 b$ & $3 b$ & $1 \mathrm{c}$ & $3 b$ & $4 a$ \\
\hline
\end{tabular}

Different letters in the same row indicate significant differences $(p<0.05)$. Number of samples $(n=10)$; AVT1 and ACT1 = non-diluted teas; AVT2 and ACT2 (dilution 1 tea:2 water v/v); AVT3 and ACT3 (dilution 1 tea:4 water v/v). 
similar inhibition of $F$. oxysporum $\mathrm{f}$. sp. lycopersici as $R$. solani, by AVT and ACT, showing a suppressive effect of $12 \%$ and 14 $\%$, respectively. On day 2 the cfu observed with the addition of AVT and ACT to the medium were above 1,000 in both cases. Both types of tea compost showed a high number of cfu, and were therefore very microbiologically active extracts. In ACT a high percentage of lactic acid bacteria, actinomycetes and Trichoderma harzianum fungus were identified, while in AVT the majority of the microbes identified were colonies of T. harzianum.

\section{In vivo assays}

The values obtained for stem diameter, root and shoot dry weight and chlorophyll content of tomato plants (uninoculated and inoculated with the pathogens) irrigated with aerated compost and vermicompost teas are shown in Table 7. After treatment with ACT and AVT the values for diameter, dry weight and chlorophyll content were significantly higher than the controls and no significant differences were observed between these treatments for uninoculated plants. Table 7 clearly outlines the positive growth effect of both compost teas on the growth of tomato plants. The results of the attack severity of $F$. oxysporum f. sp. lycopersici on inoculated plants are also shown in Table 7. Plants treated with ACT and AVT reduced $F$. oxysporum f. sp. lycopersici damage, displaying significant differences between the $F$. oxysporum f. sp. lycopersici control and both treatments $(p<0.05)$. High values for all growth parameters were observed with the application of ACT, but no significant differences with respect to the application of AVT were detected $(p<0.05)$. Results of the suppressive effect on $R$. solani disease in tomato plants by garden wastes compost tea and vermi-

Table 5 - Growth effect on tomato seedlings and attack severity of Rhizoctonia solani using different dosages of of vermicompost (AVT) and garden waste compost (ACT) teas (mean \pm standard deviation).

\begin{tabular}{|c|c|c|c|c|c|c|c|c|}
\hline & Control & $\begin{array}{c}\text { Rhizoctonia } \\
\text { Control }\end{array}$ & $\begin{array}{l}\text { Rhizoctonia } \\
\text { AVT1 }\end{array}$ & $\begin{array}{l}\text { Rhizoctonia } \\
\text { AVT2 }\end{array}$ & $\begin{array}{l}\text { Rhizoctonia } \\
\text { AVT3 }\end{array}$ & $\begin{array}{l}\text { Rhizoctonia } \\
\text { ACT1 }\end{array}$ & $\begin{array}{l}\text { Rhizoctonia } \\
\text { ACT2 }\end{array}$ & $\begin{array}{l}\text { Rhizoctonia } \\
\text { ACT3 }\end{array}$ \\
\hline Leaf area $\left(\mathrm{mm}^{2}\right)$ & $21.3 \pm 1.8 \mathrm{a}$ & $9.3 \pm 1.8 b$ & $18.4 \pm 1.5 \mathrm{a}$ & $19.1 \pm 1.7 \mathrm{a}$ & $12.6 \pm 2 b$ & $19.8 \pm 1.8 \mathrm{a}$ & $18.3 \pm 2.3 \mathrm{ab}$ & $13.5 \pm 1.3 b$ \\
\hline Chlorophyll content (SPAD units) & $20.1 \pm 1.9 a b$ & $16.8 \pm 1.2 \mathrm{c}$ & $22.3 \pm 1.1 \mathrm{a}$ & $19.6 \pm 1.8 b c$ & $23.9 \pm 1.1 \mathrm{a}$ & $20.6 \pm 2.1 \mathrm{ab}$ & $21.5 \pm 1.8 \mathrm{ab}$ & $17.1 \pm 1.7 b c$ \\
\hline Total dry weight (mg) & $47.7 \pm 3.4 \mathrm{ab}$ & $30.1 \pm 2.8 c$ & $50.3 \pm 2.7 a$ & $45.1 \pm 3.8 \mathrm{ab}$ & $34.8 \pm 4.8 b c$ & $48.8 \pm 4.1 a b$ & $41.1 \pm 2 b$ & $31.6 \pm 2.1 c$ \\
\hline Attack severity & $0 d$ & $5 a$ & $0 d$ & $1 \mathrm{c}$ & $3 b$ & $1 \mathrm{c}$ & $2 c$ & $4 \mathrm{ab}$ \\
\hline
\end{tabular}

Table 6 - Relative growth (RG), growth diameter of the pathogens $(\mathrm{mm})$ (mean \pm standard deviation). Total colonies forming units (cfu from the teas) in Petri dishes.

\begin{tabular}{|c|c|c|c|c|c|c|c|}
\hline & & $\mathrm{RG}$ & 2 days diameter & 7 days diameter & 13 days diameter & cfu (2 days) & cfu (7 days) \\
\hline & & $\%$ & & & & & \\
\hline \multirow{3}{*}{ Rhizoctonia solani } & $\mathrm{ACT}+\mathrm{R}$ & 54 & $29.0 \pm 2.4 a$ & $41.8 \pm 6.1 b$ & $46.4 \pm 4.4 b$ & $400 \mathrm{a}$ & $>1000$ \\
\hline & $\mathrm{AVT}+\mathrm{R}$ & 18 & $32.1 \pm 3.1 \mathrm{a}$ & $35.8 \pm 5.2 b$ & $15.0 \pm 1.4 c$ & $286 b$ & $>1000$ \\
\hline & Control & 100 & $32.0 \pm 2 \mathrm{a}$ & $85.0 \pm 0.1 \mathrm{a}$ & $85.0 \pm 0.1 \mathrm{a}$ & & \\
\hline \multirow{3}{*}{$\begin{array}{l}\text { Fusarium oxysporum f. sp. } \\
\text { lycopersici }\end{array}$} & $\mathrm{ACT}+\mathrm{F}$ & 12 & $21 \pm 5.4 b$ & $16 \pm 3.4 b$ & $10 \pm 3.6 b$ & $>1000$ & $>1000$ \\
\hline & $\mathrm{AVT}+\mathrm{F}$ & 14 & $27 \pm 4.1 b$ & $17 \pm 3.6 b$ & $12 \pm 3.5 b$ & $>1000$ & $>1000$ \\
\hline & Control & 100 & $40 \pm 3.4 a$ & $59 \pm 2.7 a$ & $85 \pm 0.1 a$ & & \\
\hline
\end{tabular}

Different letters in the same column indicate significant differences $(p<0.05)$. Number of samples $(n=5)$.

Table 7 - Growth effect on tomato plants and attack severity of Fusarium oxysporum f. sp. lycopersici and Rhizoctonia solani diseases using aerated compost tea (ACT) and vermicompost tea (AVT) (mean \pm standard deviation).

\begin{tabular}{|c|c|c|c|c|c|c|}
\hline & Stem diameter & Dry weight root & Dry weight shoot & $\begin{array}{l}\text { Chlorophyll content } \\
\text { (SPA units) }\end{array}$ & Number of dead plants & $\begin{array}{l}\text { Attack } \\
\text { severity }\end{array}$ \\
\hline & $\mathrm{mm}$ & 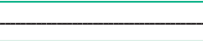 & 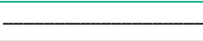 & & & \\
\hline Control & $2.92 \pm 0.8 c$ & $1.0 \pm 0.2 c$ & $2.3 \pm 0.2 c$ & $21.7 \pm 2.4 b$ & 0 & $0 \mathrm{~d}$ \\
\hline ACT & $7.84 \pm 0.9 a$ & $3.1 \pm 0.3 \mathrm{a}$ & $8.4 \pm 0.5 a$ & $28.3 \pm 2.2 \mathrm{a}$ & 0 & $0 \mathrm{~d}$ \\
\hline AVT & $7.60 \pm 1.1 \mathrm{a}$ & $2.8 \pm 0.2 \mathrm{a}$ & $7.8 \pm 0.6 a$ & $27.8 \pm 1.8 a$ & 0 & $0 \mathrm{~d}$ \\
\hline Fusarium control & $2.10 \pm 1.2 \mathrm{~cd}$ & $0.7 \pm 0.2 c$ & $1.2 \pm 0.6 \mathrm{~cd}$ & $20.0 \pm 3.6 b$ & 1 & $3 b$ \\
\hline Fusarium + ACT & $5.42 \pm 1.3 b$ & $2.6 \pm 0.2 a b$ & $5.8 \pm 0.2 b$ & $31.1 \pm 3.1 \mathrm{a}$ & 0 & $1 \mathrm{c}$ \\
\hline Fusarium +AVT & $4.04 \pm 1.4 \mathrm{~b}$ & $2.0 \pm 0.4 b$ & $4.7 \pm 0.3 b$ & $29.2 \pm 2.4 \mathrm{a}$ & 0 & $1 \mathrm{c}$ \\
\hline Rhizoctonia control & $1.32 \pm 0.9 d$ & $0.6 \pm 0.3 c$ & $0.7 \pm 0.4 \mathrm{de}$ & $19.0 \pm 3.2 b$ & 6 & $5 a$ \\
\hline Rhizoctonia+ACT & $2.62 \pm 1.1 \mathrm{c}$ & $0.9 \pm 0.2 c$ & $4.3 \pm 0.4 b c$ & $30.9 \pm 2.4 a$ & 5 & $4 a b$ \\
\hline Rhizoctonia+AVT & $4.54 \pm 1.6 b$ & $1.6 \pm 0.5 b$ & $5.1 \pm 0.2 b$ & $28.3 \pm 2.4 a$ & 3 & $3 b$ \\
\hline
\end{tabular}

Different letters in the same column indicate significant differences $(p<0.05)$. Number of samples $(n=15)$. 
compost tea are also noted in Table 7. Attack severity was reduced from 5 (R. solani control) to 3 (with AVT application). Addition of ACT reduced attack severity by only one unit. Both application of compost tea and vermicompost tea improved $R$. solani control results with respect to stem diameter, dry weight root and shoot and chlorophyll content. In this case, a relevant suppressive effect was reached with the application of $\mathrm{AVT}$, finding significant differences with respect to the addition of ACT as regards stem diameter and dry weight root. This result is in line with those obtained for in vitro assays, but the suppressive effect of AVT was not as effective. Finally, Figure 1 shows the means and standard deviations of the total dry weight of the tomato plants, comparing uninoculated control plants with those inoculated with $F$. oxysporum f. sp. lycopersici and $R$. solani pathogens, with and without compost and vermicompost tea treatments. The addition of ACT and AVT significantly improved total dry weight compared to the control and showed a clear positive growth effect, mainly attributable to the ACT treatment. Tomato plants inoculated with $R$. solani or $F$. oxysporum $\mathrm{f}$. sp. lycopersici reduced their total dry weight compared to the uninoculated control plants due to the pathogen attack being most noticeable in $R$. solani. Plants inoculated with $F$. oxysporum $\mathrm{f}$. sp. lycopersici, treated with $\mathrm{ACT}$, reached dry weights four times higher than those without the tea application. Additionally, plants inoculated with $F$. oxysporum f. sp. lycopersici treated with AVT also exhibited a significant increase in total dry weight when compared with the $F$. oxysporum f. sp. lycopersici control plants. In conclusion, the plants inoculated with either pathogen and treated with either ACT or AVT displayed significantly higher total dry weights than the corresponding controls, clearly indicating the positive effect of the application of compost teas on plant growth.

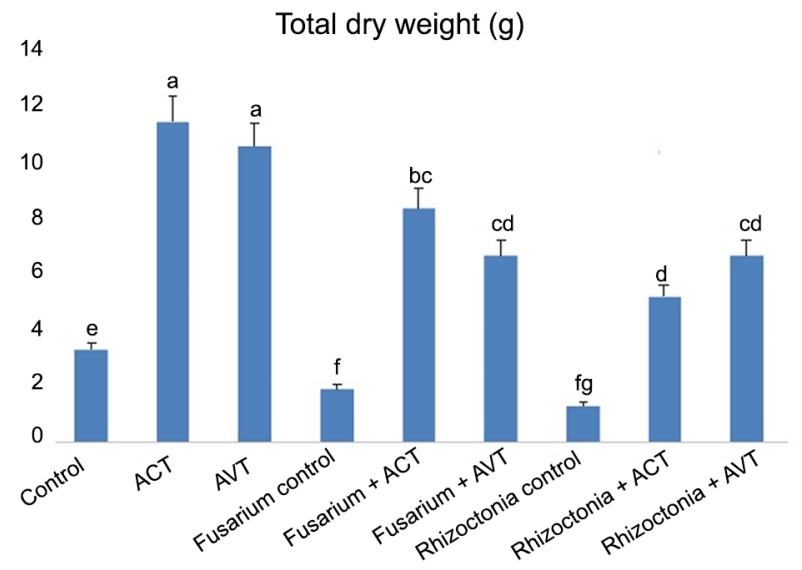

Figure 1 - The total dry weights (mean and standard deviation) of tomato plants treated with compost and vermicompost tea and inoculated with the pathogens. Different letters above the columns indicate significant differences $(p<0.05)$.

\section{Discussion}

The results of this study indicated the substantial effect of garden waste compost and vermicompost teas on tomato plant growth. The $\mathrm{pH}$ and $\mathrm{EC}$ values were within the range suitable for compost tea preparation (Naidu et al., 2010). Plant nutrient values were in both cases (AVT and ACT) higher than those obtained by Souleymane et al. (2010) for non-aerated compost teas prepared in a 1:5 $(\mathrm{v} / \mathrm{v})$ ratio from different compost and by Pant et al. $(2012$; 2013) for vermicompost extracts prepared in a $1: 10(\mathrm{v} / \mathrm{v})$ ratio. However, the nutrient values for AVT were similar to "chicken-manure vermicompost aged" from the last cited study. $\mathrm{N}$ and $\mathrm{K}$ contents were in line with those described by Naidu et al. (2010) in compost tea prepared from agricultural wastes. Moreover, the values for N, P, K, $\mathrm{Ca}$ and $\mathrm{Mg}$ were slightly lower than those found by Siddiqui et al. (2008) for teas made from empty fruit bunches of oil palm. It is clear that the origin of material used to make the compost and the extraction method greatly determine the mineral composition of the teas; a high concentration of minerals in the compost explains the high concentration of these nutrients in the teas (Pant et al., 2012). The mineral composition of teas is very similar $\left(R^{2}\right.$ correlation: 0.88$)$ to the mineral composition of compost and vermicompost used in this study, which was described by Morales-Corts et al. (2014), in which compost contains a higher mineral quantity than vermicompost. We can confirm that the efficiency of nutrient extraction is greater in the case of compost tea than in vermicompost tea. This fact was also described by Pant et al. (2012). It is important to note that the $\mathrm{N}$ and $\mathrm{K}$ levels, especially in ACT, make these teas potentially interesting as fertilizers for growing crops. Segarra et al. (2009) support this finding, indicating that compost tea prepared from garden wastes was rich in inorganic salts. In general, EC values, which are related to nutrient composition, are higher in teas prepared from thermophilic compost than those of vermicompost. As regards the presence of potentially toxic elements, chemical sensitivity analysis ensured that the levels of $\mathrm{Zn}, \mathrm{Mn}, \mathrm{Cu}, \mathrm{Pb}, \mathrm{Hg}, \mathrm{Cr}, \mathrm{Ni}$ and $\mathrm{Cd}$ were clearly below the allowable limits according to the legislation. Thus, as also indicated by Benito et al. (2005) and Moretti et al. (2015), consideration of the source of green material used in composting is important for ensuring the absence of toxic metals. The presence of IAA in compost and vermicompost teas may be linked to the green waste material used in composting, and the presence of salicylic acid could be related to both microbial productions during composting, and to the origin of green material. The phytohormone values found in this study, especially salicylic acid were high comparable to those obtained by Pant et al. (2012). This could be due to the presence of salicylic acid in the bark used in composting (trees from the Salicaceae and Cuppressaceae families). Both ACT and AVT presented humic acids in their composition, which could explain the positive effect on the growth of tomato plants. Mora et al. (2012) reported the coordinated positive ac- 
tion of humic substances on root and shoot growth. Also, Scotti et al. (2015) pointed to an increase in secondary roots treated with humic acids and compost tea in tomato plants. Therefore, the clear growth effect of both compost teas on tomato plants, as observed in this study, could be explained not by any one single factor but by a combination of factors, such as nutrient composition, humic acids, the presence of phytohormones and the beneficial effects of microorganisms.

Very few studies have been carried out involving the application dosages of compost teas. Most frequently, teas are applied directly as they are extracted, without dilution. Pane et al. (2012) suggested that to prevent phytotoxic reactions from occurring, it is necessary to dilute compost teas in water before being applied to plants. In our study, undiluted ACT and AVT were more efficient in enhancing plant growth (Table 3) and the suppressive effect on pathogen attack (Tables 4 and 5) than the diluted extracts. Hence, if ACT or AVT is applied in a diluted dosage, the suppressive effect will be reduced. Nevertheless, Al-Dahmani et al. (2003) studied the effect of compost to water ratio $(1: 1,1: 3$ and $1: 5$ to make the tea) on efficacy against bacterial spot and they did not find a correlation between suppressive effect and compost tea concentration. In no case were phytotoxic symptoms found in the tomato plants of our study. Morales-Corts et al. (2014) highlighted the absence of phytotoxicity in compost and vermicompost from garden wastes by germination index analysis (GI). Therefore, when making compost teas it is useful to determine their GI to decide if they should be diluted before being applied.

Following the in vitro experiments, applications of $\mathrm{ACT}$ and $\mathrm{AVT}$, which were extracted in a volumetric ratio of $1: 5$, were consistently effective in reducing the severity of $F$. oxysporum f. sp. lycopersici attack compared to the water control and the diluted dosages, where plants treated with ACT had higher total dry weights than those treated with AVT. The same result was obtained in the experiment where tomato plants were grown in pots with $F$. oxysporum f. sp. lycopersici inoculum (Table 7). Therefore, the results are consistent in that the application of ACT reduces the incidence of $F$. oxysporum f. sp. lycopersici disease, even with the high amount of inoculum applied.

No relationship between the pathogen attack and the nutrients of the teas could be considered in this study because the volumetric ratio of 1:5 did not in any case increase the attack severity with respect to the diluted teas. Although nutrient addition (mainly $\mathrm{C}$ sources for microorganisms) is commonly suggested for improving disease suppression (Ingham, 2005), in certain cases foods such as molasses must be used with extreme caution because they encourage saprophytic growth of pathogens and may neutralize the potential of biological control (Ingham, 2005; Scheuerell, 2003). Martín (2014) indicated that further investigations are needed to test nutrient amendments of teas for their effect on both targeted plant pathogens and non-targeted human patho- gens, as well as the overall disease suppressive efficacy of compost tea.

Studies applying different compost teas to reduce the incidence of Fusarium spp. have been reported by Ma et al. (2001), El-Masry et al. (2002), Bonanomi et al. (2006), Kerkeni et al. (2007), Alfano et al. (2011), Xu et al. (2012) and Tian and Zheng (2013), who obtained different results compared to disease control. Thus, as indicated by Marín et al. (2014), each compost tea has a unique behavior and should be individually tested to check its interaction with a specific pathogen. In regard to this, Ros et al. (2005) pointed out that green compost applied to soil may be used to control diseases such as Fusarium spp. wilt. These authors indicated that the root-compost interaction inhibits the access of pathogens to the plant by creating a film of microorganisms, which acts by a system of mycoparasitism, competition and the production of antibiotics to prevent the pathogen from entering the plant. In accordance with these results, compost tea (ACT) contains a high level of $T$. harzianum, actinobacteria and lactic acid bacteria that could be involved in this system. Naidu et al. (2010) consider the microbial population in the compost tea relevant to its effectiveness, highlighting the role of pseudomonas, lactic acid bacteria, actinomycetes, Trichoderma spp. and other fungi. Nevertheless, certain composts derived from vegetal residues contain a high quantity of aromatic compounds that actively inhibit phytopathogenic fungi, and, as indicated by Scotti et al. (2015), contain soluble organic molecules, such as humic substances, and antagonistic bacteria and fungi that play a crucial role in plant protection.

With respect to $R$. solani, positive control of the pathogen was reported by Weltzien (1989) using composted organic materials, particularly green residues. Authors, such as Suárez-Estrella et al. (2012) and Tian and Zheng (2013), analysed in vitro the suppressive effect of different compost teas. The biocontrol of different crops has been studied (Kerkeni et al., 2007; Tateda et al., 2012; Pane et al., 2013 and Sabet et al., 2013), wherein the level of pathogenicity of $R$. solani was reduced using different compost teas. Diánez et al. (2007) reported that lignocellulosic wastes induce specific suppression of $R$. solani by Trichoderma spp., which are often present in garden waste mature compost. Additionally, Krause et al. (2001) related the suppression of $R$. solani to the presence of microbial antagonism in the compost. These results are in line with our in vitro and in vivo studies in which a clear suppressive effect on $R$. solani was obtained compared to the control when using undiluted AVT and ACT. Moreover, vermicompost tea was more efficient than compost tea in terms of reducing attack severity and producing an increase in total dry weight of the plants. Thus, we can conclude that the use of AVT could be more effective in controlling $R$. solani than ACT. Similarly, Arancon et al. (2007), using vermicompost teas of different organic residues, observed a notable reduction in incidence of $R$. solani in different crops. In comparison, we found in our assays 
carried out in petri dishes that AVT was more effective than ACT. This result could be due to the very high frequency of Trichoderma sp. present in AVT (Bollo, 1999) and the coelomic fluid produced by earthworms (Gutiérrez-Miceli et al., 2007).

Thus, it is important to note that on day 2 , in the experiments carried out in petri dishes, the growth of $F$. oxysporum f. sp. lycopersici was reduced by almost half compared to the control, when ACT or AVT were included in the media. By day 13 the growth of $F$. oxysporum $\mathrm{f}$. sp. lycopersici was significantly reduced to $12 \%$ and 14 $\%$, respectively, compared to the control. Both ACT and AVT showed positive biocontrol by reducing pathogen colony growth by more than $50 \%$ (Bernal-Vicente et al., 2008). However, clear inhibition of $R$. Solani growth was observed by day 7 . The presence of many microbial colonies was also observed, resulting from the germination of $T$. harzianum spores present in the AVT, which clearly contributed to the reduction in the growth of $R$. solani by both antagonistic and parasitic effect. In support of this, Pane et al. (2013) in a study involving agricultural waste-based composts exhibiting suppression of $R$. sola$n i$, also reported that microbial communities play a major role in biological control. As indicated by Elad and Shtienberg (1994), the effect of the extraction time taken to prepare the compost teas ( 14 days in our study) is relevant to the achievement of significant suppression. These authors state that extraction should last for more than 10 days in order to be effective in the control of pathogenic diseases. Thus, the use of ACT seems clearly positive, and according to the in vitro and in vivo assays, has a stronger effect on the control of $F$. oxysporum $\mathrm{f}$. sp. lycopersici, whereas the control of $R$. solani is slightly reduced and not as effective. Furthermore, Segarra et al. (2009) also confirmed the suppressive effect obtained using aerated compost tea from garden waste compost on tomato plants, and pointed out that the effect of the compost could be attributable to the presence of bacteria and fungi acting antagonistically against the pathogen.

The analysis of the growth effect on tomato plants clearly indicates that both ACT and AVT when applied weekly produce a positive effect on stem diameter, shoot and root dry weight and chlorophyll content compared to that on control plants. ACT and AVT enhance the growth of plants and triple their total dry weight. This improvement in the weight of shoots and roots by using compost teas corroborates previous studies (Hargreaves et al., 2009; Marín et al., 2014). Pant et al. (2009; 2012) found a positive influence on the growth of Brassica rapa with the minerals $\mathrm{N}$ and $\mathrm{AG}_{4}$. This finding is in agreement with our results in which $\mathrm{N}$ levels and IAA composition could be the principal explanation for the growth effect on tomato plants. Masson et al. (1991) noted that dry matter content influences plant resistance to stress caused by both biotic and abiotic conditions. Consequently, when the dry matter content is greater the plants are more resistant to pathogens such as $F$. oxysporum f. sp. lycopersici and $R$. solani.
In spite of the lower amount of nutrients in AVT (especially $\mathrm{K}$ content), plant growth with AVT application was statistically similar to that submitted to ACT application. Gutiérrez-Miceli et al. (2007), in studies regarding the cultivation of Sorgum bicolor, reported that vermicompost leachate, with a mineral composition quite similar to that used in this study, can be used as liquid fertilizer. Moreover, Arancon et al. (2006) reported that the increase in strawberry plant growth by application of vermicompost was mainly due to the microbial population. Following Edwards et al. (2006), plant growth hormones, such as auxins, dissolved during the brewing period used to make the teas could be responsible for the increase in tomato plant growth. This may have occurred in our study, where the increase in tomato growth could have been related to the nutrients, growth promoters (humic acids and phytohormones) and microorganisms found in both teas. Thus, the growth and suppressive effect of garden waste compost and vermicompost teas could be both biotic and abiotic in origin for most compost teas, as indicated by Zmora-Nahum et al. (2008).

In conclusion, this study demonstrates the high potential of garden waste aerated compost and vermicompost teas on tomato growth and the suppressive effect on $R$. solani and $F$. oxysporum f. sp. lycopersici. Garden waste aerated compost tea presents a high level of nutrients, such as $\mathrm{N}$ and $\mathrm{K}$, which contain phytohormones IAA and salicylic acid, humic acids and microorganisms that can promote growth plant and help in the biocontrol of fungal pathogens. Garden waste aerated compost tea produced a high suppressive effect on $F$. oxysporum f. sp. lycopersici whereas vermicompost tea achieved a better result in controlling $R$. solani. Weekly applications of both compost and vermicompost teas tripled the dry weight of tomato plants. The positive results of this study have allowed the production method of garden wastes compost and vermicompost teas to be standardized (dilution ratio of 1:5 compost: water, 15 days of brewing time, with $4 \mathrm{~h}$ of aeration per dayl with the consequence that direct application of undiluted teas has proven to be the most effective. The use of these compost teas are of great interest to organic and sustainable agriculture.

\section{Acknowledgments}

This research was supported by Projects FS/4-2013 and USAL2015-10 from Salamanca University.

\section{References}

Aendekerk, G.L.; Cevat, H.; Dolmans, N.; van Elderen, C.; Kipp, J.A.; de Kreij, C.; Sonneveld, C.; Verhagen, J.B.G.M.; Wever, G. 2000. International Substrate Manual: Analysis, Characteristics, Recommendations. Elsevier International, Amsterdam, The Netherlands. 
Agencia Estatal Boletín Oficial del Estado [BOE] 2013. Royal Decree 506/2013, June 28, on Fertilizer Products = Real Decreto 506/2013, de 28 de Junio, sobre Productos Fertilizantes. Boletín Oficial del Estado, Sec. I, n. 164, p. 51119, Madrid, Spain (in Spanish).

Al-Dahmani, J.H.; Abbasi, P.A.; Miller, S.A.; Hoitink, H.A.J. 2003. Suppression of bacterial spot of tomato with foliar sprays of compost extracts under greenhouse and field conditions. Plant Disease 87: 913-919.

Alfano, G.; Lustrato, G.; Lima, G.; Vitullo, D.; Ranalli, G. 2011. Characterization of composted olive mill wastes to predict potential plant disease suppressiveness. Biological Control 58: 199-207.

Arancon, N.Q.; Edwards, C.A.; Bierman, P. 2006. Influences of vermicomposts on field strawberries. Part 2. Effects on soil microbiological and chemical properties. Bioresource Technology 97: 831-840.

Arancon, N.Q.; Edwards, C.A.; Dick, R.; Dick, L. 2007. Vermicompost tea production and plant growth impacts. Biocycle 48: 51-52.

Astegiano, E.D.; Favaro, J.C.; Bouzo, C.A. 2001. Estimation of leaf area in different tomato cultivars (Lycopersicum esculentum Mill.) using linear leaf measures = Estimación del área foliar en distintos cultivares de tomate (Lycopersicum esculentum Mill.) utilizando medidas foliares lineales. Investigación Agraria: Producción y Protección Vegetales 16: 249-256 (in Spanish).

Baayen, R.P.; van der Plas, C.H. 1992. Localization ability, latent period and wilting rate in eleven carnation cultivars with partial resistance to Fusarium wilt. Euphytica 59: 165-174.

Benito, M.; Masaguer, A.; De Antonio, R.; Moliner, A. 2005. Use of pruning waste compost as a component in soilless growing media. Bioresource Technology 96: 597-603.

Bernal-Vicente, A.; Ros, M.; Tittarelli, F.; Intrigliolo, F.; Pascual, J.A. 2008. Citrus compost and its water extract for cultivation of melon plants in greenhouse nurseries: evaluation of nutriactive and biocontrol effects. Bioresource Technology 99: 8722-8728.

Bollo, E. 1999. Vermiculture: An Alternative for Recycling = Lombricultura: Una Alternativa de Reciclaje. Soboc Grafic, Quito, Ecuador (in Spanish).

Bonanomi, G.; Giorgi, V.; Giovanni, D.S.; Neri, D.; Scala, F. 2006. Olive mill residues affect saprophytic growth and disease incidence of foliar and soilborne plant fungal pathogens. Agriculture, Ecosystems \& Environment 115: 194-200.

Carling, D.E.; Leiner, R.H. 1990. Virulence of isolates of Rhizoctonia solani AG-3 collected from potato plant organs and soil. Plant Disease 74: 901-903.

Diánez, F.; Santos, M.; Tello, J.C. 2007. Suppressive effects of grape marc compost on phytopathogenic oomycetes. Archives of Phytopathology and Plant Protection 40: 1-18.

Edwards, C.A.; Arancon, N.Q.; Greytak, S. 2006. Effects of vermicompost teas on plant growth and disease. Biocycle 47: 28-31.

Egwunatum, A.; Lane, S. 2009. Effects of compost age on the suppression of Armillaria mellea with green waste compost teas. Compost Science \& Utilization 17: 237-240.

Elad, Y.; Shtienberg, D. 1994. Effect of compost water extracts on grey mould (Botrytis cinerea). Crop Protection 13: 109-114.
El-Masry, M.; Khalil, A.; Hassouna, M.; Ibrahim, H. 2002. In situ and in vitro suppressive effect of agricultural composts and their water extracts on some phytopathogenic fungi. World Journal of Microbiology and Biotechnology 18: 551-58.

Food and Agriculture Organization [FAO]. 2015. Faostat: agriculture data. Available at: http://faostat3.fao.org/faostatgateway/go/to/download/ [Accessed Sept 15, 2015]

Gutiérrez-Miceli, F.A.; Santiago-Borraz, J.; Montes-Molina, J.A.; Nafate, C.C.; Abud-Archila, M.; Oliva-Llaven, M.A.; RincónRosales, R.; Deendoven, L. 2007. Vermicompost as a soil supplement to improve growth, yield and fruit quality of tomato (Lycopersicum esculentum). Bioresource Technology 98: 2781-2786.

Hargreaves, J.C.; Adl, M.; Warman, P.R. 2009. Are compost teas an effective nutrient amendment in the cultivation of strawberries? Soil and plant tissue effects. Journal of the Science of Food and Agriculture 89: 390-397.

Ingham, E.R. 2005. The Compost Tea Brewing Manual. Soil Food Web, Corvallis, OR, USA.

International Organization for Standardization [ISO]. 2002. Microbiology of Food and Animal Feeding Stuffs - Horizontal Method for the Detection of Salmonella spp. ISO, Geneva, Switzerland.

International Organization for Standardization [ISO]. 2015. Microbiology of the Food Chain - Horizontal Method for the Enumeration of Beta-Glucuronidase-Positive Escherichia Coli Part 3: Detection and Most Probable Number Technique Using 5-bromo-4-chloro-3-indolyl-ß-d-glucuronide. ISO, Geneva, Switzerland.

Kerkeni, A.; Daami-Remadi, M.; Tarchoun, N.; Khedher, M.B. 2007. In vitro assessment of the antifungal activity of several compost extracts obtained from composted animal manure mixtures. International Journal of Agricultural Research 2: 786-794.

Köller, W.; Wilcox, W.F. 2001. Evidence for the predisposition of fungicide-resistant isolates of Venturia inaequalis to a preferential selection for resistance to other fungicides. Phytopathology 91: 776-781.

Krause, M.S.; Madden, L.V.; Hoitink, H.A. 2001. Effect of potting mix microbial carrying capacity on biological control of Rhizoctonia damping-off of radish and Rhizoctonia crown and root rot of poinsettia. Phytopathology 91: 1116-1123.

Ma, L.; Qiao, X.; Gao, F.; Hao, B. 2001. Control of sweet pepper Fusarium wilt with compost extracts and its mechanism. Chinese Journal of Applied \& Environmental Biology 7: 8487.

Marín, F.; Diánez, F.; Santos, M.; Carretero, F.; Gea, F.J.; Castañeda, C.; Navarro, M.J.; Yau, J.A. 2014. Control of Phytophthora capsici and Phytophthora parasitica on pepper (Capsicum annuum L.) with compost teas form different sources, and their effects on plant growth promotion. Phytopathology Mediterranea 53: 216-228.

Martin, C.C.S. 2014. Potential of compost tea for suppressing plant diseases. CAB Reviews 9: 1-38.

Masson, J.; Tremblay, N.; Gosselin, A. 1991. Nitrogen fertilization and HPS supplementary lighting influence vegetable transplant production. I. Transplant growth. Journal of the American Society for Horticultural Science 116: 594-598. 
Mora, V.; Baigorri, R.; Bacaicoa, E.; Zamarreño, A.M.; GarcíaMina, J.M. 2012. The humic acid-induced changes in the root concentration of nitric oxide, IAA and ethylene do not explain the changes in root architecture caused by humic acid in cucumber. Environmental and Experimental Botany 7: 24-32.

Morales-Corts, M.R.; Gómez-Sánchez, M.A.; Pérez-Sánchez, R. 2014. Evaluation of green/pruning wastes compost and vermicompost, slumgum compost and their mixes as growing media for horticultural production. Scientia Horticulturae 172: 155-160.

Moretti, S.M.L.; Bertoncini, I.B.; Abreu-Junior, C.H. 2015. Composting sewage sludge with green waste from tree pruning. Scientia Agricola 72: 432-439.

Naidu, Y.; Meon, S.; Kadir, J.; Siddiqui, Y. 2010. Microbial starter for the enhancement of biological activity of compost tea. International Journal of Agriculture \& Biology 12: 51-56.

Pane, C.; Celano, G.; Villecco, D.; Zaccardelli, M. 2012. Control of Botrytis cinerea, Alternaria alternata and Pyrenochaeta lycopersici on tomato with whey compost-tea applications. Crop Protection 38: 80-86.

Pane, C.; Piccolo, A.; Spaccini, R.; Celano, G.; Villecco, D.; Zaccardelli, M. 2013. Agricultural waste-based composts exhibiting suppressivity to diseases caused by the phytopathogenic soil-borne fungi Rhizoctonia solani and Sclerotinia minor. Applied Soil Ecology 65: 43-51.

Pant, A.P.; Radovich, T.J.; Hue, N.V.; Talcott, S.T.; Krenek, K.A. 2009. Vermicompost extracts influence growth, mineral nutrients, phytonutrients and antioxidant activity in pak choi (Brassica rapa cv. Bonsai, Chinensis group) grown under vermicompost and chemical fertiliser. Journal of the Science of Food and Agriculture 89: 2383-2392.

Pant, A.P.; Radovich, T.J.; Hue, N.V.; Paull, R.E. 2012. Biochemical properties of compost tea associated with compost quality and effects on pak choi growth. Scientia Horticulturae 148: 138146.

Pascual, J.A.; Garcia, C.; Hernandez, T.; Lerma, S.; Lynch, J.M. 2002. Effectiveness of municipal waste compost and its humic fraction in suppressing Pythium ultimum. Microbial Ecology 44: 59-68.

Paulitz, T.C.; Schroeder, K.L. 2005. A new method for the quantification of Rhizoctonia solani and $R$. oryzae from soil. Plant Disease 89: 762-772.

Reeve, J.R.; Carpenter-Boggs, L.; Reganold, J.P.; York, A.L.; Brinton, W.F. 2010. Influence of biodynamic preparations on compost development and resultant compost extracts on wheat seedling growth. Bioresource Technology 101: 5658-5666.

Ros, M.; Hernandez, M.T.; Garcia, C.; Bernal, A.; Pascual, J.A. 2005. Biopesticide effect of green compost against fusarium wilt on melon plants. Journal of Applied Microbiology 98: 845854.
Sabet, K.K.; Saber, M.M.; El-Naggar, M.A.-A.; El-Mougy, N.S.; El-Deeb, H.M.; El-Shahawy, I.E.-S. 2013. Using commercial compost as control measures against cucumber root-rot disease. Journal of Mycology 2013: article ID 324570. doi. org/10.1155/2013/324570

Scotti, R.; D'Ascoli, R.; Gonzalez Caceres, M.; Bonanomi, G.; Sultana, S.; Cozzolino, L.; Rao, M.A. 2015. Combined use of compost and wood scraps to increase carbon stock and improve soil quality in intensive farming systems. European Journal of Soil Science 66: 463-475.

Segarra, G.; Reis, M.; Casanova, E.; Trillas, M.I. 2009. Control of powdery mildew (Erysiphe polygoni) in tomato by foliar applications of compost tea. Journal of Plant Pathology 91: 683-689.

Scheuerell, S. 2003. Understanding how compost tea can control disease. BioCycle 44: 20-25.

Siddiqui, Y.; Meon, S.; Ismail, R.; Rahmani, M.; Ali, A. 2008. Bio-efficiency of compost extracts on the wet rot incidence, morphological and physiological growth of okra Abelmoschus esculentus [(L.) Moench]). Scientia Horticulturae 117: 9-14.

Siddiqui, Y.; Meon, S.; Ismai, R.; Rahmani, M. 2009. Bio-potential of compost tea from agro-waste to suppress Choanephora cucurbitarum L. the causal pathogen of wet rot of okra. Biologycal Control 49: 38-44.

Souleymane, B.K.; Dionne, A.; Russell, J.T.; Hani, A.; Tyler J.A. 2010. Suppressive effect of non-aerated compost teas on foliar fungal pathogens of tomato. Biological Control 52: 167-163.

Suárez-Estrella, F.; Bustamante, M.; Moral, R.; Vargas-García, M.; López, M.; Moreno, J. 2012. In vitro control of Fusarium wilt using agroindustrial subproduct-based composts. Journal of Plant Pathology 94: 59-70.

Tateda, M.; Yoneda, D.; Sato, Y. 2012. Effects of Compost Tea Making from Differently Treated Compost on Plant Disease Control. JSPS/VAST, Osaka, Japan.

Tian, X.; Zheng, Y. 2013. Compost teas and reused nutrient solution suppress plant pathogens in vitro. HortScience 48: 510-512.

Weltzien, H.C. 1989. Some effects of composted organic materials on plant health. Agriculture, Ecosystems \& Environment 27: 439-446.

Xu, D.; Raza, W.; Yu, G.; Zhao, Q.; Shen, Q.; Huang, Q. 2012. Phytotoxicity analysis of extracts from compost and their ability to inhibit soil-borne pathogenic fungi and reduce root-knot nematodes. World Journal of Microbiology and Biotechnology 28: 1193-1201.

Zmora-Nahum, S.; Danon, M.; Hadar, Y.; Chen, Y. 2008. Chemical properties of compost extracts inhibitory to germination of Sclerotium rolfsii. Soil Biology and Biochemistry 40: 2523-2529. 